\title{
NON-FARM ENTERPRISES AND SECONDARY CHILD SCHOOLING IN INDONESIA
}

\author{
${ }^{* 1}$ Susilo, Hendrawan, ${ }^{2}$ Satria, Dias \\ ${ }^{*}$ Faculty of Economics and Business, Universitas Brawijaya, Malang, Indonesia \\ ${ }^{2}$ Faculty of Economics and Business, Universitas Brawijaya, Malang, Indonesia \\ Note: * Indicates corresponding author
}

\begin{tabular}{|c|}
\hline ARTICLE DETAILS \\
\hline JEL Classification: \\
\hline D13; I25; I28. \\
\hline $\begin{array}{l}\text { Keywords } \\
\text { non-farm enterprise, secondary } \\
\text { education, logistic regression, } \\
\text { propensity score matching, school } \\
\text { participation }\end{array}$ \\
\hline${ }^{*}$ Corresponding Author \\
\hline Email: hendrawanbsusilo@gmail.com \\
\hline
\end{tabular}

\begin{abstract}
This study aims to examine the influence of ownership of non-farm enterprises by households on child participation in a secondary school in Indonesia; this area of research has received scant attention in recent times. This paper uses the Indonesia Family Life Survey (IFLS) data set that contains different levels of data, ranging from individual-level data to community-level data for the analysis. Using a binomial logistic regression model, this study finds that the ownership of non-farm enterprises generally increases the likelihood of children participation in secondary education, especially senior high school. Further estimation using propensity score matching demonstrates that households with non-farm enterprises tend to have a higher spending on school expenses than those that do not have non-farm enterprises.
\end{abstract}

\section{Introduction}

Investment in human capital, especially in children's education, is a central policy in many developing countries. The increase and expansion of education have become the main agenda of developing countries and development institutions (Kilburn, Handa, Angeles, Mvula, \& Tsoka, 2017). Indonesia, as developing countries experiencing a low enrollment rate, especially in secondary education. Based on the Indonesia Statistic data of 2014, the national net enrollment rates in upper secondary and lower secondary are $55.88 \%$ and $76.55 \%$, respectively. Although the government has intervened with various policies, such as school operational assistance, cash transfer for poor students, and education infrastructure development, the secondary net enrollment rate remains low.

With regard to the Indonesian context, where the majority of the population lives in rural areas, there is a particular topic that is currently being discussed by researchers - role of ownership of non-farm enterprises by households, especially in developing countries where agriculture is a major sector. Various studies have discussed the role of non-farm Faculty of Economics and Business,

Brawijaya University enterprises as an engine of economic development, especially in rural areas, for increased household income (Oostendorp et al., 2009), poverty reduction (McCulloch et al., 2011), and increased household wellbeing (Shehu \& Sidique, 2014). However, the manner in which non-farm enterprises' ownership contributes to human resource development, especially enrollment at the secondary school level, remains unclear.

Previous research has identified various determinants of school participation. A few researchers highlighted educational program policies (Duflo et al., 2017), access to family microcredit (Bhuiya et al., 2019), and the effect of parental health on children's school participation (Lim, 2019) as determinants. Concerning studies on secondary school participation in Indonesia, researchers have investigated the influence of individual student characteristics, household characteristics, and community characteristics (Chernichovsky \& Meesook, 1985; Suryadarma et al., 2006; Takahashi, 2011). The most recent research on secondary education in Indonesia emphasizes the local government policies (Prasetyia, 2019). However, only limited research explores family income sources, especially non-farm 


\section{Non-farm Enterprise and Secondary Child Schooling in Indonesia}

enterprises, as a driving factor for children's school participation. Research linking non-farm enterprises with school participation has been carried out by Janssens et al. (2019) in Ghana; however, their research focuses on women's role as the owners of non-farm enterprises.

This research aims to fill the gaps in the existing body of literature by examining the relationship between non-farm enterprise ownership and children's opportunities to attend secondary school. Linking individuals, households, community facilities, and the ownership of non-farm enterprises will enable us to comprehensively observe the micro determinants of the decision to send children to secondary schools. Understanding the effect of non-farm enterprise ownership on the propensity of secondary enrollment of children can assist policymakers in developing new strategies for increasing secondary school participation in Indonesia.

\section{Literarture Review}

The interest of economists and policymakers in the link between human capital investment and a country's economic growth has increased rapidly in the last few decades. According to Romer (1990), the rate of economic growth is not only influenced by the increase in physical capital but also the increase in human capital. In developing countries, labor is one of the most abundant production factors. On the other hand, the limitation of physical capital is a country's main obstacle. Hence, it is crucial to improve the quality of human resources (Lucas, 1988; Romer, 1986).

Sustainable economic development requires a strategic role in the field of education, especially to facilitate the accumulation of human capital that can support increased production and other activities (Satria, 2008). Schultz (1961), who researched human capital in the 1950's to 1960's, argued that education was instrumental in increasing human capital and provided people with strength and power. Education becomes an investment due to the expected return in the form of a better future life (G. Becker, 1964; G. S. Becker, 1962). Regarding the investment of education, every individual will compare the costs incurred for schools with the benefits derived from being educated. The marginal rate of return for school demand adjusts to the income and production costs of the additional unit costs used for schools, while the marginal cost or supply of schools depends on the investment costs (Sharma, 2014). Although human capital accumulation is a product of individual decisions, decisions related to investment in developing countries for children are generally a household decision (de Hoop \& Rosati, 2014; Glomm, 1997; Rosati, 2003)

\subsection{Education System in Indonesia}

In order to discuss the school enrollment at the secondary school level, it is essential to understand the Indonesian education system. The education structure in Indonesia consists of four levels: pre-primary school, primary education, secondary education, and tertiary education. Pre-primary is the education level for children aged 3-6. Children aged 7-12 must attend a part of primary education. The following level, secondary education, is for children aged 13-18. Secondary education consists of junior secondary and senior secondary; each section lasts for three years. The highest level is tertiary education, which consists of universities, polytechnics, and colleges.

Law Number 20 of 2003 requires children aged $7-15$ to undergo compulsory education (elementary and junior high school). In Indonesia, this is called the nine-year compulsory education program. By law, the government has been given the mandate to allocate $20 \%$ of the government expenditure on education. Furthermore, the government also provides education subsidies through the School Operational Assistance Program or BOS, which is a governmental grant program for financing direct school costs (Prasetyia, 2019). This program targets all schools at the primary and junior high school levels, both government and private, throughout Indonesia. In 2014, the government launched a twelve-year compulsory education program up to the level of upper secondary education. Along with this, the government expanded the scope of BOS to the senior high school level; however, it has not been able to make senior high school free of cost. Therefore, parents must continue to provide funds for indirect educational costs. The cash transfer program, called Program Indonesia Pintar (PIP), is another government effort to facilitate compulsory education to help poor students cover indirect costs. The government also provides educational cash transfer through social safety nets, such as the Program Keluarga Harapan for the poorest group.

\subsection{Determinants of School Enrollment}

Many studies have researched the determinants of school enrollment. In this paper, the focus will be on the literature review regarding the determinants of school enrollment 
publication in developing countries, especially Indonesia. Most prior researchers based their research on the influence of individual, parental, household, and community characteristics as determinants of secondary education participation.

For individual characteristics, many researchers chose the child's age, gender, and child labor as essential factors in children's school enrollment. In his research, Grimm (2011) found that boys have a higher likelihood of participation in secondary school. Similarly, Suryadarma et al. (2006) showed that in comparison to boys, girls have a lower chance of transitioning to junior high school.

On the other hand, research conducted by Takahashi (2011) in Indonesia suggested that gender disparities have gradually disappeared in secondary education. Suryadarma et al. (2006) also discovered that children who work have a lower school participation compared to children who do not. However, Mussida et al. (2019) found that children can work while still attending school. Abafita \& Kim (2015) found that the child's age has a significant effect on the probability of children participating in school. This finding is in line with research conducted by Gönsch (2010), which stated that in the case of the Dominican Republic and Haiti, the older the children, the more the likelihood of school participation.

Concerning parental characteristics, three variables have been widely used: the age of the household head, female-headed household, and parent's years of schooling. One of the most critical factors in school participation is parental education, as children who come from educated parents have a higher probability of attending secondary education (Grimm, 2011; Handa, 2002; Kilburn et al., 2017; Suryadarma et al., 2006; Takahashi, 2011; Tansel, 2002). A higher level of parent education positively correlates with their awareness for investing in education (Handa, 2002; Tansel, 1997). The age of the household head influences children's school participation; usually, the older the parents, the more savings they have. More savings indicate that the parents have more resources to allocate to their children's education (Susilo \& Tri, 2020).

In terms of household characteristics, some studies mention the family's social and economic status, such as household expenses, land ownership (Giang \& Nguyen, 2017; Irfan, 1995; Olaniyan, 2011), and household dependency ratio (Sabates et al., 2019). In developing countries that experience limited public spending, children who come from poor households often drop out because their parents cannot afford to pay for education (Suryadarma

Faculty of Economics and Business,

Brawijaya University et al., 2006). Glick \& Sahn (1999) found that increasing household income would consequently increase human capital investment in girls through school participation. Suryadarma et al. (2006) demonstrated that the level of household welfare consequently determines the level of participation in the school. In research regarding school enrollment in Indonesia, land ownership had a positive effect on children's secondary education participation (Susilo \& Tri, 2020). In India, land ownership encourages parents to enroll their children in secondary education (Dostie \& Jayaraman, 2006). The dependency ratio is another household characteristic that influences children's school enrollment. A study of school responses to changes in family income by Sabates et al. (2019) revealed that the dependency ratio negatively correlated to the children's school enrollment.

In terms of community characteristics, the availability of schools, availability of public transportation, and student-teacher ratio are the factors that have been generally recognized as those influencing school participation (Connelly \& Zheng, 2003; Olaniyan, 2011; Prasetyia, 2019; Suryadarma et al., 2006; Tansel, 2002). Research conducted in India by Dostie \& Jayaraman (2006) explained that access to roads in terms of public transportation has a positive effect on children's school participation. Prasetyia (2019) stated that the likelihood of child enrollment in secondary education increases as the number of schools in the region rises. Duflo (2001), who examined mass school development programs in Indonesia during the Suharto administration, found that the program increased children's duration of schooling as well as school participation. School quality is one of the aspects that influence the decision to send children to school (Tansel, 2002). Concerning the quality of schools, in this study, we followed Tansel's work by proxying it with the teacherstudent ratio in an area.

\subsection{Non-Farm Enterprises and Child Education}

The non-farm enterprises of households in this study are all household business activities outside the agricultural sector and are based on the Indonesia Family Life Survey (IFLS) definition. Here, the non-agricultural sector refers to the definition of Central Statistics Agency (BPS). The majority of household nonfarm enterprises in Indonesia are small-trading and small-scale manufacturing businesses (Gibson \& Olivia, 2010). Based on the IFLS data, the type of non-farm enterprises in Indonesia are mainly micro trading, such as warung and small 


\section{Non-farm Enterprise and Secondary Child Schooling in Indonesia}

food processing businesses.

Various studies have discussed the role of NFE as an engine of economic development (especially in rural areas), increased household income, poverty reduction, and child labor (AlAmin \& Hossain, 2019; Haggblade et al., 2007; Lanjouw, 2001; Oostendorp et al., 2009; Shehu \& Sidique, 2014). Usually, this business is an additional activity undertaken by households to diversify their sources of income.

Owing to the fact that non-farm enterprises play a vital role in households, the influences of household non-farm enterprises on children's education, especially at the secondary level, are examined in this study. Theoretically, the influence of non-farm-enterprise ownership by families on children's education can be explained through two channels: through the positive effect of increasing family income from non-farm enterprise activities and through the negative effect of the labor substitution, where the child will be asked to work in the household business, causing them to choose not to go to school (Janssens et al., 2019).

Research that emphasizes the link between non-farm enterprises and child schooling is scarce. Most studies investigate the link between non-farm enterprises and poverty alleviation. These studies focus on increased household income with business diversification in the non-agricultural sector (Hoang et al., 2014; Kuiper et al., 2007; Mat et al., 2012). Janssens et al. (2019) examined the effect of NFE on child schooling within the context of the sub-Saharan country, Ghana; they emphasized mothers' NFE ownership. Their study concluded that NFE has the potential to stimulate the participation of school children who have poorer and less educated mothers, and this is very important in efforts to reduce educational inequality in rural areas.

According to previous theories and related research, it can be concluded that the ownership of a non-farm family business will affect the time and resource allocation for children's school participation. In theory, families will maximize their utility with limited time and budgets. They will allocate their limited time and resources to obtain maximum utility, including the allocation of their resources for their child's education.

\section{Research Methods}

This study uses the fifth wave (the latest wave) of the Indonesia Family Life Survey (IFLS) 2014 the data source. IFLS is a longitudinal survey based on households. It covers 13 provinces in Indonesia, with four provinces in Java and four provinces in outside Java, and it represents $83 \%$ of population. The fifth-wave Faculty of Economics and Business,

Brawijaya University
IFLS survey covered 16,204 households in 4,600 villages, including more than 50,000 individuals.

The data relates to the children aged 1219, with three levels of data (individual, household and community-facilities). Individual, household, and parental characteristics were taken from the household section of IFLS. The data on educational facilities (community level) was taken from the community and facility sections of IFLS 2014. Upon matching with all levels, the data obtained contained 5,895 individual samples, obtained from children aged 12-19 with their corresponding household and community levels.

The binomial logit model has been used to analyze the effect of ownership of non-farm enterprises on the likelihood of a child's participation in secondary school. This model was developed from a combination of models used by other researchers (Bui et al., 2020; Janssens et al., 2019; Suryadarma et al., 2006; Takahashi, 2011), with little modification. The specifications of the models used in this study are as follows:

$$
\begin{aligned}
& \mathrm{Li}=\ln \left(\frac{P i}{1-P i} \frac{P i}{1-P i}\right) \\
& J H S_{\text {cphm }}=\beta_{0^{+}}+N F E+\beta X_{c}+\beta Y_{p}+\beta X_{h}+\beta X_{m} \ldots \ldots . . \text { model } 1 \\
& S H S_{c p h m}=\beta_{0}+N F E+\beta X_{c}+\beta Y_{p}+\beta X_{h}+\beta X_{m} \ldots \ldots . . . \text { model } 2 \\
& S S_{c} c_{c h m}=\beta_{0}+N F E+\beta X_{c}+\beta Y_{p}+\beta X_{n}+\beta X_{m} \ldots . . \text { model } 3
\end{aligned}
$$

Where $c$ is an individual characteristic, $p$ is a parent characteristic, $h$ is a household characteristic, and $m$ is a community characteristic. An operational definition in this study is explained in Appendix 1.

To determine the difference in school expenditure between families that have nonfarm enterprises and those that do not have nonfarm enterprises, the propensity score matching (PSM) technique was employed. The PSM technique was used to observe the difference effect of having non-farm enterprises on the school expense of each group by matching the attribute variables of households that have nonfarm enterprises (NFE) and those that do not have it. The average treatment on treated (ATT) of non-farm enterprise households can be estimated as the difference effect between those who get treatment (have NFE) and those who do not.

To estimate the PSM, the observations were divided into two groups; a treated group with NFE and a control group without NFE. Then an estimate was carried out using the probit regression to estimate the propensity value of 
each observation from the group that received the treatment. After obtaining the propensity score of each observation, the propensity was stratified and balanced across the treatment group and the untreated group. The independent variables used for the matching are shown in Appendix 2.

The next step involved matching the observations of the treated and control groups based on the propensity value. In this study, the radius-matching methods were used. Two different matching methods (nearest neighbor and kernel) to perform the sensitivity analysis test were employed. Upon matching the observation, the average treatment on treated effects were calculated. The ATT can be defined as follows:

Average Treatment on Treated (ATT) (5)

$$
\Delta=y 1-y 0(6)
$$

$A T T=E(\Delta)=E(y 1 \mid x, D=1)-E(y 0 \mid x, D=1)(7)$

ATT is the average outcome (school expenditure) difference between the treated group (household with NFE) and the control group (household without NFE) in observation.

\section{Results and Discussion}

Appendix 3 provides the results from the three models: It consists of standard error, odds ratio, and significance. The odds ratio is the relationship between exposure and outcome; this value shows the comparison of the likelihood of a child attending secondary school with certain characteristics compares with the possibility without the presence of certain characteristics. The following is the result of PSM for the school expenditure between households with non-farm enterprise and households without non-farm enterprise. These results are provided in Appendix 5, consisting of three different matching methods: radius matching, nearest neighbor matching, and kernel matching.

The results of the logistic regression for the main independent variable (non-farm enterprise) displayed various results. Model 1 (junior high school-aged level) shows that there is no significant effect between non-farm enterprise and school enrollment. Model 2 (senior high school-aged level) and Model 3 (secondary school-aged level) show significant relation and have a positive direction between non-farm enterprises and school. The children from households that have non-farm enterprises more likely to attend school 1.29 and 1.21 times in model 2 and model 3 respectively.

The results of the logistic regression Faculty of Economics and Business, Brawijaya University estimate for various control variables that are known to have a relationship with secondary education can be explained using each model as follows:

In Model 1 (junior high school-aged children), the control variables related to school enrollment with a significance value are the child age, child working status, female headed household, parent's years of schooling, dependent ratio, and the teacher-student ratio. The variable of children's age reduces the likelihood of children's school enrollment by 0.76 times for each increase in value, while in the variable of the child's working status, it reduces the likelihood of school enrollment by 0.94 times. In the parent characteristic group, femaleheaded households have a negative effect, while the years of the parent's schooling positively affected the likelihood of children's school enrollment. The variable of female-headed households decreased the probability of the child's school enrollment in junior high school by 0.43 times. Moreover, every unit increased for the years of parent's schooling consequently increased the probability of children enrolling in school by 1.067 .

The regression results on Model 2 (senior high schools children) show that seven control variables have a significant effect: the child's age; the child's working status, female child variables have a significant and negative effect, with odds ratios of $0.53,0.105$, and 0.76 respectively. In the parent characteristic variable group, parents' ages show a negative impact; every unit increase in parents' age reduces the likelihood of the child attending school by 0.989 . The parents' years of schooling significantly affect the probability of child enrolling in school with a positive impact of a 1.026 an odd ratio. The monthly expenditure is significant; however, the value of odds ratio is approximately 1.00 . This shows an absence of a significant difference. For the community characteristic group, only the teacher-student ratio has a significant effect with an odds ratio of 3.5.

The results of Model 3 (sample of secondary school-aged children) show that eight control variables have a significant relationship on the children's probability of school enrollment. All three variables show a negative and a significant effect on the child's characteristics with the odd ratio of the children's ages (0.67), the child's working status (0.11), and female child (0.82). In terms of parents' characteristics, all three variables have a significant effect but different directions. The head of households and female headed households appear to be decreasing children's propensity to enroll in school with the odds ratios 0.99 and 0.80 


\section{Non-farm Enterprise and Secondary Child Schooling in Indonesia}

respectively. The monthly expenditures appear to be significant, but the odds ratio is too small and approximately zero. Regarding the community characteristics, increasing the teacher student ratio will increase the probability of children secondary school enrollment by 3.12 times.

Prior to interpreting the ATT result of PSM, the descriptive result of each group with their matching attributes needs to be observed. It can be seen in Table 3 that the differences between the treated and control group are not significant. The ATT results of the PSM test using dependent variables of school expense and matching attribute for the total log asset, female headed household, dependent ratio, head of household age, and parent years of schooling show interesting results that support the main findings. With a different matching method, several average treatment effects are obtained, but they always have consistent results. The results show that school expenditure on households with non-farm enterprises is higher compared to households without non-farm enterprises. The following are the results for the methods: IDR 1,889,769.06 (radius matching), $1,554,269.05$ (nearest neighbor), and IDR $1,289,79.04$ (kernel method).

\subsection{Non-Farm Enterprise and Secondary Education}

This study investigated a number of determinants that focus on family ownership of non-farm enterprises as a factor in household decisions of sending their children to school for secondary education. Overall, the results (Model 3) confirm the basic hypothesis of this study that ownership of household non-farm enterprise has a significant and positive effect on household decisions of sending their children to secondary school.

The relationship between the non-farm family enterprise ownership and secondary schooling was positive and significant. The nonfarm enterprise ownership only has a positive and significant effect at the senior high school level but not at the junior high school level. Overall, the logistic regression results show that children from families with non-farm enterprises tend to attend school at the high school level 1.21 times higher than those from families without non-farm enterprises. The children who come from families with non-farm enterprises were also 1.287 times more likely to enroll in senior high school as compared to children who came from families without non-farm enterprises.

The condition mentioned above could be related to the out-of-pocket costs that must be Faculty of Economics and Business, Brawijaya University paid by families who have children who could be enrolled in senior high school. The out of pocket costs may consist of transportation costs because the locations of senior high schools are usually located in the center of the sub-district, and these are limited in numbers. In addition, the costs of schooling for senior high school children are higher than junior high school children.

Furthermore, the subsidies provided by the government in Indonesia for the junior high school level have generally been able to make junior high schools more universal than senior high schools. Various subsidies and government interference for junior high school education have been effectively implemented. These programs include school operational assistance funds, cash transfers through the Smart Indonesia Program (PIP), and Family Hope Program (PKH). Parents do not spend an exorbitant amount of out-of-pocket money for the junior high school level since it is, in terms of relativity, highly subsidized. From a macro perspective, it can be seen that the nine-year compulsory education up to junior high school is quite successful, with the net enrollment rate in 2014 of $76.55 \%$.

In line with these conditions, the research conducted by several experts on non-farm businesses in Indonesia found that non-farm businesses have the potential to stabilize the incomes of the poor (Gibson \& Olivia, 2010; Hill, 2001; Tambunan, 2000). The non-farm businesses in Indonesia are essential in diversifying income in order to add an additional source of income. With the increase in income obtained from non-farm enterprises, families that have non-farm enterprises have a greater probability of enrolling their children in the senior high school level compared to families that do not have non-farm enterprises.

To ensure whether households with nonfarm enterprise have a higher propensity to enroll their children in secondary education, a test was conducted using the PSM technique with a proxy for school expenditures for each family. As seen in Table 5, the descriptive statistics of the observable variable between two groups shows that there are no significant differences, except for school expenses for each group. This indicates no selection bias in the sample matching attributes. It can be seen from the descriptive result that households with nonfarm enterprise have a higher mean of school expenses than households without a non-farm enterprise. The condition indicates that non-farm enterprise households tend to spend more on school expenditures than households without a non-farm enterprise. To verify the difference, a propensity score matching test was conducted. 
The ATT result presented in Table 4 indicates that non-farm enterprises have a significant and positive effect on school expenditure for households. This is particularly the case for the ATT value where the radius matching is IDR $1,889,769.06$ (USD 131). To ensure the result is not biased, a sensitivity test was performed where two matching methods (kernel and nearest neighbor) were employed. The results from the test confirm that the ATT is robust. The ATT results show that households that have non-farm enterprises had higher school expenditure in one year than household without a non-farm enterprise. These results confirm that families who have non-farm enterprises have a greater likelihood of enrolling their children in secondary school than those who do not because they appear to have higher school expenses.

This value is high compared to the value of government subsidies in allocating BOS funds where the allocation per student in a year is IDR $1,100,000.00$ (USD 76.44) for JHS and IDR $1,500,000.00$ (USD 104) for SHS. Since the government covers its operational cost for school, non-farm enterprise households generally have a higher out of pocket expense than household without non-farm enterprise.

\subsection{Non-Farm Enterprise and Secondary Education}

In addition to the main independent variables of non-farm enterprise ownership, the control variables were also tested. These control variables are divided into four groups: individual, parent, household, and community characteristics.

\section{A. Individual Characteristics}

The variables of individual characteristics in this study consist of the child's age, child working status, and gender of the child. Previous studies have considered individual characteristics as an important determinant of school enrollment. In the three research samples, it can be seen that all three variables have significant and negative results with the exception of female child at the junior high school level. The logistic regression results depict that older the children, lower is their likelihood of going to school. An interesting finding is that the influence of the variable of children's ages in the senior high school-aged children is higher (0.40) compared to the junior high school-aged level (0.77). This result is in line with research conducted by Owusu-Addo et al. (2020), which reveals that in a situation where parents are unable to enroll all their children in school, the oldest child is usually not a priority; that child usually assists in generating family income. In the context of Indonesia, the oldest Faculty of Economics and Business,

Brawijaya University child feels responsible for helping generate the family income. They usually choose to work to help the family economy and provide financial support for their younger siblings to go to school, especially in poor areas.

The variable working status is significant in three models; the variable of working status has a negative effect. The logistic regression results show that at all levels of school, the children who work have a lower chance to be enrolled in secondary education. This finding is in line with the findings in the research conducted by Susilo \& Tri (2020), using the Indonesia Socio Economic Survey of 2018. This survey found that child labor reduces the child's chances of going to school. The research conducted by Owusu-Addo et al. (2020) regarding the conditions of developing countries, parents usually expect children who are aged $16-18$ to help them work, especially in rural areas.

The logistic regression results on gender in the three models show that two models have significant results for this variable. Concerning the female child variable at the junior high school level, there is no significant effect; however, it decreased the propensity of a child attending school at the senior high level. These findings indicate that gender disparities in access to junior secondary disappear but not in senior secondary schools. This condition is in line with Gender Parity Index (GPI) score published by the Central Bureau of Statistics. In 2014, the GPI for the SHS level was 0.85 and the JHS was 1.04. These findings confirm the research finding regarding developing countries, which states that girls have fewer chances than boys to attend secondary school (Glick \& Sahn, 1999; Maertens \& Verhofstadt, 2013). This condition shows that there is a burden for female children to participate in senior high school in Indonesia.

B. Parent Characteristics

The parent characteristics' variables consist of the age of the household's head, femaleheaded household, and parent's years of schooling. In the variable of the length of schooling of the head of the family, all models show significant and positive results. An increase of one year of parent's schooling increases a child's chances of being in junior high school by 1.06 times, while in SHS, it increases by 1.026 times, and 1.04 times for the entire sample. This finding is in line with the findings of Tansel (1997) where it is reported that higher the education of parents, the higher is parents' awareness regarding the importance of children's education as part of an investment. Education will provide provisions for children in facing the labor market, and parents also hope to receive returns from their children. 


\section{Non-farm Enterprise and Secondary Child Schooling in Indonesia}

Female headed households seem affected by the propensity of a child to be enrolled in junior high school; however, it is not significant in senior high school. This might be the case because in Indonesia, female-headed households are more financially fragile than male households. Based on the IFLS data, female-headed households are single-parent households and have lower monthly expenditures. Data from the sample shows that the average monthly expenditure from a femaleheaded household, which is IDR 5,140,230 (USD 357), is lower than a male-headed household is IDR 6,996,883 (USD 486)

Regarding the variable of the age of the household's head, only the junior high school and secondary education models shows significant results and have a positive direction. The variable of the age of the household's head shows that having older parents increases the propensity of children's participation in secondary school. The explanation for this finding is that the older the age, the more savings parents usually have, and the family is ready to invest some of its money in children's education. However, according to the result, this condition only occurs in senior high school-aged level. It might be correlated with highly subsidized junior high school level and nine-year compulsory education program since 1994. Education may be seen as an obligation set by the government on all citizens.

\section{Household Characteristics}

The control variable of household characteristics consists of monthly expenses, the dependency ratio, and land ownership. The most prominent finding is the monthly expenditure variable; however, it is only significant in the two models (senior high school and secondary education) and has a positive impact. On the other hand, the odds ratio is close to zero, so it means that there is no difference in terms of monthly expenditure to send their children to secondary education. The dependency ratio variable is only significant at the junior high school level, but interestingly, a higher dependency ratio increases the likelihood of children attending school. This finding may suggest that in junior high school level, households tend to enroll their children in school because it is free and does not affect the household productivity to generate income.

The variable of family's land value describes the wealth of the family. The regression results show that none of the three models were significant. This condition is in contrast with the results of research conducted by Glick and Sahn (1999), Grimm (2011), and Tansel (1997), which states that the wealth of the household is an essential determinant of children's participation in secondary school. This might have happened because land has a low return on increased family income. The utilization of land has a reasonably low valueadded value compared to other commodities, especially in rural area.

\section{Community Characteristics}

The characteristics of the control variable group of the community consist of the number of schools in the sub regency, the ratio of teachers to students, and the availability of public transportation. The most prominent finding is the teacher-student ratio that is significant for three models. The ratio of the presence of teachers for students dramatically increases children's chances of attending school. This finding shows that the government's role is still very dominant in influencing the net enrollment rate at all levels of secondary education. This condition is in line with the current condition in Indonesia, which is still experiencing a limited number of teachers, especially in rural and remotes areas. Teachers are still concentrated in sub-district centers.

This study examined several factors that are key factors in a household's decision to enroll their children in secondary education, focusing on the effect of ownership of a non-farm enterprise. In general, it can be concluded that the ownership of non-farm enterprises has a significant and positive influence on sending children to secondary education. This finding is confirmed by the propensity score matching test, which shows that households with non-farm enterprises tend to spend a higher average school expense that approximately amounts to IDR 1,889,769.06 (USD 131). However, if we separate the secondary education level in junior and senior high school level, the ownership of non-farm enterprises only affects children's school decisions at the senior high school level.

The following are some significant findings included in this study: the eldest child has a higher magnitude influence on the lowering likelihood of children attending senior high school than junior high school. The results indicate that children at senior high school are more likely to not go to school and do other work instead. This finding aligns with the test results on the working status variable, which is only significant in two models other than the junior high school model. Children at the age of senior high school are usually expected to help their parents to increase family income.

The second finding that has a large magnitude is the teacher-student ratio, which has a significant and positive relationship in all models with an odds ratio of 3.12 to 3.5 times. This finding indicates that providing educational 
facilities has a dominant effect on children's chances of attending secondary school. It also shows that the role of the government as the largest provider of educational facilities has a considerable influence.

\section{Conclusion}

This study aimed to examine the influence of ownership of non-farm enterprises on the child secondary school participation in Indonesia. Past research has identified various determinants of school participation. However, the limited research in this area emphasizes family income sources, especially non-farm enterprises, as a driving factor for children's school participation. This study attempts to fill gaps in the existing body of literature by examining the relationship between non-farm enterprise ownership and children's opportunities to attend secondary school.

The results showed that ownership of nonfarm enterprises by the family generally increases the tendency of children to attend secondary school, especially at the senior high school level; however, this is not the case at the junior high school level. This finding is supported by the PSM test results, which showed that households with non-farm enterprises tend to tend to spend more expenditure on school expenses than those that do not.

There was another interesting finding in the study: older children tend to be burdened to attend secondary education. Child labor lowers the chance of a child attending school. Parents who have received higher education are more concerned with their child's education. Moreover, the role of the government in providing educational facilities, especially the number of teachers, has a tremendous impact on children's participation in secondary school.

Although the government has intervened on the supply side of education (for example, education infrastructure development, BOS) and the demand side (for example, PIP, PKH), the secondary net enrollment rate remains quite low. For senior secondary school level that requires out of pocket expenses from households, government intervention-especially on the demand side of education-is not enough. A new strategy such as encouraging non-farm enterprise may be one of the solutions that could be parallel with interventions in the supply side.

Several government policies that can be considered as complementing the existing policies include encouraging community empowerment programs, especially those related to the empowerment of non-farm enterprises. These are included as a complementary strategy in increasing family

Faculty of Economics and Business,

Brawijaya University income, which will fill out-of-pocket costs for school fees. This development can be in the form of an effort to increase the role of the community in building a business, providing easy access to capital and increasing production and marketing skills. Given the government's major role in influencing the supply side of education, efforts may be made to increase educational facilities, especially increasing the number of competent teachers throughout Indonesia.

The purpose of this paper was to investigate the effect of ownership of a non-farm enterprise on school participation. The non-farm enterprises in this study were only limited to household non-farm enterprises. This study did not focus on farm households; it also did not compare farm enterprises with non-farm enterprises. Hence, farm enterprises were not included in this study. Future research can include household farm enterprises and make specific observations between rural and urban areas. This can be carried out to compare the role of farm enterprises with that of non-farm enterprises as one of the micro determinants in children's school participation.

\section{Refrences}

Abafita, J., \& Kim, C. (2015). 'Determinants of children's schooling: The case of Tigray Region', Ethiopia. Educational Research and Reviews, 10(8), 11301146.

Al-Amin, A. K. M. A., \& Hossain, M. J. (2019). 'Impact of non-farm income on welfare in rural Bangladesh: Multilevel mixedeffects regression approach', World Development Perspectives, 13(February), 95-102.

Barrett, C. B., Reardon, T., \& Webb, P. (2001). 'Nonfarm income diversification and household livelihood strategies in rural Africa: Concepts, dynamics, and policy implications', Food Policy, 26(4), 315331

Becker, G. S. (1964). Human capital theory. Columbia, New York, 1964.

Becker, G. S. (1962). 'Investment in human capital: A theoretical analysis', Journal of Political Economy, 70(5), 9-49.

Bhuiya, M. M. M., Khanam, R., Rahman, M. M., \& Nghiem, S. (2019). 'Microcredit participation and child schooling in rural Bangladesh: Evidence from a crosssectional survey', Economic Analysis and Policy, 64, 293-301.

Bui, T. A., Nguyen, C. V., Nguyen, K. D., Nguyen, H. H., \& Pham, P. T. (2020). 


\section{Non-farm Enterprise and Secondary Child Schooling in Indonesia}

'The effect of tuition fee reduction and education subsidy on school enrollment: Evidence from Vietnam', Children and Youth Services Review 108,104536

Chernikovsky, D., \& Meesook, O. A. (1985). School enrollment in Indonesia. The World Bank.

Connelly, R., \& Zheng, Z. (2003). 'Determinants of school enrollment and completion of 10 to 18 year olds in China', Economics of Education Review.

De Hoop, J., \& Rosati, F. C. (2014). 'Cash transfers and child labor', The World Bank Research Observer, 29(2), 202234.

Dostie, B., \& Jayaraman, R. (2006). 'Determinants of school enrollment in Indian villages', Economic development and cultural change, 54(2), 405-421.

Duflo, E., Dupas, P., \& Kremer, M. (2017). 'The impact of free secondary education: Experimental evidence from Ghana', Massachusetts Institute of Technology Working Paper Cambridge, MA.

Ellis, F. (1998). 'Household strategies and rural livelihood diversification'. Journal of Development Studies, 35(1), 1-38.

Giang, L. T., \& Nguyen, C. V. (2017). 'How would cash transfers improve child welfare in Viet Nam?', Children and Youth Services Review, 82, 87-98.

Gibson, J., \& Olivia, S. (2010). 'The effect of infrastructure access and quality on non-farm enterprises in rural Indonesia', World Development, 38(5), 717-726.

Glick, P., \& Sahn, D. E. (1999). 'Schooling of girls and boys in a West African country: The effects of parental education, income, and household structure', Economics of Education Review, 19(1), 63-87.

Glomm, G. (1997). 'Parental choice of human capital investment', Journal of Development Economics, 53(1), 99114.

Gönsch, I. (2010). 'Determinants of primary school enrollment in Haiti and the Dominican Republic', Discussion Paper.

Grimm, M. (2011). 'Does household income matter for children's schooling? Evidence for rural Sub-Saharan Africa', Economics of Education Review, 30(4), 740-754.

Haggblade, S., Hazell, P., Reardon, T. (2007). 'Transforming the Rural Non-Farm Economy: Opportunities and Threats in

Faculty of Economics and Business,

Brawijaya University the Developing World', International Food Policy Research Institute. Baltimore: Johns Hopkins University Press, USA

Handa, S. (2002). 'Raising primary school enrolment in developing countries: The relative importance of supply and demand', Journal of Development Economics, 69(1), 103-128.

Hill, H. (2001). 'Small and medium enterprises in Indonesia: Old policy challenges for a new administration', Asian survey, 41(2), 248-270.

Hoang, T. X., Pham, C. S., \& Ulubaşoğlu, M. A. (2014). 'Non-farm activity, household expenditure, and poverty reduction in rural Vietnam: 2002-2008', World Development, 64, 554-568.

Irfan, M. (1995). 'Determinants of child school enrolment: Evidence from LDCs using choice-theoretic approach', International Journal of Social Economics, 22(1), 2440.

https://doi.org/10.1108/0306829951007 5113

Janssens, C., Van den Broeck, G., Maertens, M., \& Lambrecht, I. (2019). 'What if mothers are entrepreneurs? Non-farm businesses and child schooling in rural Ghana', Journal of Rural Studies, 66, 95-103.

Kilburn, K., Handa, S., Angeles, G., Mvula, P., \& Tsoka, M. (2017). 'Short-term impacts of an unconditional cash transfer program on child schooling: Experimental evidence from Malawi', Economics of Education Review, 59, 63-80.

Kuiper, M., Meijerink, G., \& Eaton, D. (2007). 'Rural livelihoods: Interplay between farm activities, non-farm activities and the resource base', In Science for Agriculture and Rural Development in Low-Income Countries, Roetter, R., van Keulen, H., Kuiper eds, 77-95, Springer.

Lanjouw, P. (2001). 'Nonfarm employment and poverty in rural El Salvador', World Development, 29(3), 529-547.

Lucas, R. E. (1988). 'World development report', Journal of Monetary Economics, 22(February), 3-42.

Maertens, M., \& Verhofstadt, E. (2013). 'Horticultural exports, female wage employment and primary school enrolment: Theory and evidence from Senegal', Food Policy, 43, 118-131..

Mat, S. H. C., Jalii, A. Z. A., \& Harun, M. (2012). 
'Does non-farm income improve the poverty and income inequality among agricultural household in rural Kedah?', Procedia Economics and Finance, 1(12), 269-275.

McCulloch, N., Timmer, C. P., \& Weisbrod, J. (2007). Pathways out of Poverty during and Economic Crisis: An empirical assessment of rural Indonesia. World Bank Publications.

Mussida, C., Sciulli, D., \& Signorelli, M. (2019). 'Secondary school dropout and work outcomes in ten developing countries', Journal of Policy Modeling, 41(4), 547567.

Olaniyan, O. (2011). 'The determinants of child schooling in Nigeria', AERC Research paper 217 African Economic Research Consortium, January 2011.

Oostendorp, R. H., Trung, T. Q., \& Tung, N. T. (2009). 'The changing role of non-farm household enterprises in Vietnam', World Development, 37(3), 632-644.

Owusu-Addo, E., Renzaho, A. M. N., \& Smith, B. J. (2020). 'Developing a middle-range theory to explain how cash transfers work to tackle the social determinants of health: A realist case study', World Development, 130, 104920.

Prasetyia, F. (2019). 'The role of local government policy on secondary school enrolment decision in Indonesia', Eurasian Economic Review, 9(2), 139172.

Reardon, T., Berdegué, J., Barrett, C. B., \& Stamoulis, K. (2007). Household income diversification into rural nonfarm activities. Transforming the rural nonfarm economy: opportunities and threats in the developing world, 115140.

Romer, P. M. (1986). 'Increasing returns and long-run growth', Journal of Political Economy, 94(5), 1002-1037.

Romer, P. M. (1990). 'Human capital and growth: Theory and evidence', CarnegieRochester Confer. Series on Public Policy, 32(C), 251-286.

Rosati, F. C. (2003). 'Children's working hours and school enrollment: Evidence from Pakistan and Nicaragua', The World Bank Economic Review. 17(2), 283-295.

Sabates, R., Bhutoria, A., Sabates-Wheeler, R., \& Devereux, S. (2019). 'Schooling responses to income changes: Evidence from unconditional cash transfers in Rwanda', International Journal of Educational Research, 93, 177-187.

Satria, D. (2008). 'Modal manusia dan globalisasi: Peran subsidi pendidikan (Human capital and globalization: The role of educational subsidies)', Institute for Development of Economics and Finance (INDEF), 2(3), 7-9.

Schultz, T. W. (1961). 'Investment in human capital: Reply', The American Economic Review, 51(1), 1-17.

Sharma, D. (2014). 'Bridging human capital and social capital theories', In Value creation, reporting, and signaling for human capital and human assets (pp. 113-140). Palgrave Macmillan, New York.

Shehu, A., \& Sidique, S. F. (2014). 'A propensity score matching analysis of the impact of participation in non-farm enterprise activities on household wellbeing in rural Nigeria', UMK Procedia, 1, 26-32.

Suryadarma, D., Suryahadi, A., \& Sumarto, S. (2006). Causes of low secondary school enrollment in Indonesia. Jakarta: SMERU Research Institute.

Susilo, H., \& Tri, S. (2020). 'Keeping rural children's hope to stay in the senior high school through conditional cash transfer: An Indonesian case', Sebelas Maret Business Review, 5(1), 1-16.

Takahashi, K. (2011). 'Determinants of Indonesian rural secondary school enrolment: Gender, neighbourhood and school characteristics', Bulletin of Indonesian Economic Studies, 47(3), 395-413.

Tambunan, T. (2000). 'The performance of small enterprises during economic crisis: Evidence from Indonesia', Journal of Small Business Management, 38, 93101.

Tansel, A. (1997). 'Schooling attainment, parental education, and gender in Cote d'Ivoire and Ghana', Economic Development and Cultural Change, 45(4), 825-856.

Tansel, A. (2002). 'Determinants of school attainment of boys and girls in Turkey: Individual, household and community factors', Economics of Education Review, 21(5), 455-470. 


\section{Non-farm Enterprise and Secondary Child Schooling in Indonesia}

\section{Appendix 1.}

Operational Definition of Variables for Logistic Regression.

\begin{tabular}{|c|c|c|}
\hline Variable & Abbrev. & Definition \\
\hline \multicolumn{3}{|l|}{ Dependent Variable } \\
\hline Junior High School & $J H S$ & $\begin{array}{l}\text { School participation for children aged } 12-15 \text { in junior high } \\
\text { school (dummy variable). This was derived from the } \\
\text { definition of net enrollment on junior high school by } \\
\text { statistics of Indonesia, and this includes } 12 \text { years old } \\
\text { children because usually in Indonesia, children start to } \\
\text { enroll in junior high school at age } 12 \text {. }\end{array}$ \\
\hline Senior High School & SHS & $\begin{array}{l}\text { School participation for children aged } 16-19 \text { in high school } \\
\text { (dummy variable). Similarly, the sample from government } \\
\text { definition of net enrollment rate is expanded. }\end{array}$ \\
\hline Secondary Education & SE & $\begin{array}{l}\text { School participation for children aged } 12-19 \text { in junior high } \\
\text { and senior high school (dummy variable). }\end{array}$ \\
\hline \multicolumn{3}{|l|}{ Independent Variable } \\
\hline \multicolumn{3}{|l|}{ Main Independent Variable } \\
\hline NFE (Non-farm Enterprises) & NFE & Dummy variable for ownership of NFE by households \\
\hline \multicolumn{3}{|l|}{$\begin{array}{l}\text { Individual Characteristics } \\
\text { Variables }\end{array}$} \\
\hline Age & age_c & Children's age, measured by years \\
\hline Child's working status & work_stat & Working status of the child (dummy variable) \\
\hline Female child & fe_child & A dummy score for recording a child's gender \\
\hline \multicolumn{3}{|l|}{ Parent Characteristics } \\
\hline $\begin{array}{l}\text { Age of the Head of } \\
\text { Household }\end{array}$ & hh_age & The ages of the familiy's head \\
\hline Female-headed household & fe_HH & $\begin{array}{l}\text { The head of the household is a woman (dummy variable). } \\
\text { woman }=1, \operatorname{man}=0\end{array}$ \\
\hline Parent Year of Schooling & p_YOS & The length of education by the head of the family. \\
\hline \multicolumn{3}{|l|}{ Household Characteristics } \\
\hline Monthly Expenditure & mo_exp & Household expenditure in a month (in rupiahs) \\
\hline Land Owned & land & The value of land that owned by household in \\
\hline Dependency Ratio & dep_ratio & $\begin{array}{l}\text { The ratio of family age, between the number of non- } \\
\text { productive age family members and the productive age in } \\
\text { the family }\end{array}$ \\
\hline \multicolumn{3}{|l|}{$\begin{array}{l}\text { Community Characteristics } \\
\text { Variables }\end{array}$} \\
\hline Public Transportation & $\operatorname{trans}$ & $\begin{array}{l}\text { The availability of public transportation at the sub-district } \\
\text { level (dummy variable). Available }=1 \text {. Not available }=0\end{array}$ \\
\hline Number of School & no_school & $\begin{array}{l}\text { Number of junior high schools in the sub-district where } \\
\text { children live }\end{array}$ \\
\hline Teacher-student ratio & TS_rat & The ratio between teacher and student in the sub-district \\
\hline
\end{tabular}




\section{Appendix 2.}

Operational Definition of Variables for Propensity Score Matching.

\begin{tabular}{|c|c|c|}
\hline Variable & Abrrev & Definition \\
\hline \multicolumn{3}{|l|}{ Treated Variable } \\
\hline Non-farm Enterprise & NFE & $\begin{array}{l}\mathrm{D}=1 \text { for observations that have NFE and } \mathrm{D}=0 \text { if the } \\
\text { observations have no NFE. }\end{array}$ \\
\hline \multicolumn{3}{|l|}{ Outcome Varible } \\
\hline School Expenditure & Sch_exp & School expenditure by household in Rupiah \\
\hline \multicolumn{3}{|l|}{$\begin{array}{l}\text { Independet Variablel } \\
\text { Matching Attributes }\end{array}$} \\
\hline Log_total asset & $\begin{array}{l}\text { Log_asse } \\
\mathrm{t}\end{array}$ & Log of total asset value owned by household \\
\hline Female headed househol & Fe_hh & Dummy variable $=1$ if head of house hold is female \\
\hline Dependent ratio & Dep_rat & $\begin{array}{l}\text { The ratio of family age, between the number of non- } \\
\text { productive age family members and the productive } \\
\text { age in the family }\end{array}$ \\
\hline Household head age & Hh_age & Age of family head \\
\hline Parent year of Schooling & $P_{-}$YOS & The length of education by the head of the family. \\
\hline
\end{tabular}

\section{Appendix 3.}

Estimation Result Summary of Logistic Regression on Child School Enrollment in Secondary Education.

\begin{tabular}{|c|c|c|c|c|c|c|}
\hline \multirow[t]{3}{*}{$\begin{array}{l}\text { Independent } \\
\text { Variable }\end{array}$} & \multicolumn{2}{|c|}{$\begin{array}{c}\text { Model } 1 \\
\text { Junior High School }\end{array}$} & \multicolumn{2}{|c|}{$\begin{array}{c}\text { Model } 2 \\
\text { Senior High School }\end{array}$} & \multicolumn{2}{|c|}{$\begin{array}{c}\text { Model } 3 \\
\text { Secondary School }\end{array}$} \\
\hline & Coeff. & Odds & Coeff. & Odds & Coeff. & Odds \\
\hline & & Ratio & & Ratio & & Ratio \\
\hline NFE & .132775 & 1.141993 & $.2528708 * * *$ & 1.287717 & $1916847 * * *$ & 1.211288 \\
\hline \multicolumn{7}{|l|}{ Child Characteristic } \\
\hline Child Ages & $\begin{array}{l}- \\
.2551541 * * *\end{array}$ & .7747971 & - $6313514 * * *$ & .5318726 & $.4021119 * * *$ & 6689059 \\
\hline \multirow{2}{*}{ Child Work Status } & - & & & & & \\
\hline & $\begin{array}{l}2.0746478 * * \\
*\end{array}$ & .1256008 & $2.252128 * * *$ & .1051751 & $2.193987 * * *$ & .1114715 \\
\hline Female Child & -.0979108 & .9067297 & $.2746483 * * *$ & .7598393 & $.1960008 * * *$ & .8220115 \\
\hline \multicolumn{7}{|l|}{ Parent } \\
\hline HH_age & -.0016917 & .9983097 & $.0101225 * * *$ & .9899285 & $-.0026309 * *$ & .9973725 \\
\hline Female_HH & $.4292525 * * *$ & 6509955 & -.0247021 & .9756005 & $-.221144 * * *$ & .8016012 \\
\hline Parent_YOS & $.064667 * * *$ & 1.066804 & $.0261293 * *$ & 1.026474 & $.0439829 * * *$ & 1.044964 \\
\hline \multicolumn{7}{|c|}{ Household Characteristic } \\
\hline $\begin{array}{l}\text { Monthly } \\
\text { expenditure }\end{array}$ & $9.63 e-09$ & 1 & $2.01 \mathrm{e}-08 * * *$ & 1 & $1.49 \mathrm{e}-08 * * *$ & 1 \\
\hline Depend Ratio & $.1837724^{*}$ & 1.201742 & -.0439503 & .9570015 & .0381288 & 1.038865 \\
\hline Family's Land & $-1.13 e-10$ & 1 & $-3.98 \mathrm{e}-10$ & 1 & $-3.36 \mathrm{e}-10$ & 1 \\
\hline \multicolumn{7}{|c|}{ Community Characteristic } \\
\hline $\begin{array}{l}\text { Faculty of Economic } \\
\text { Brawijaya Universit }\end{array}$ & ad Business, & & 56 & & & \\
\hline
\end{tabular}


Non-farm Enterprise and Secondary Child Schooling in Indonesia

$\begin{array}{lllllll}\text { No. School in Sub } & -.021959 & .9782803 & .0145383 & 1.014645 & .0016826 & 1.001684 \\ \text { Teacher-Student } & 1.140348^{*} & 3.127856 & 1.255328 * * & 3.50899 & 1.140719^{* *} & 3.129018 \\ \text { ratio } & .0282069 & 1.028608 & .0598524 & 1.06168 & .0309745 & 1.031459 \\ \text { Public Transport } & 4.280112 & 72.2485 & 10.87559 & 52870.18 & 6.479941 & 651.9323 \\ \text { _cons } & 246.58 & & 888.77 & & 2092.39 & \\ \text { LR chi2 } & 0.0000 & & 0.0000 & & 0.0000 & \\ \text { Prob > chi2 } & 0.0798 & & 0.2251 & & 0.2593 & \\ \text { Pseudo R2 } & & 3,004 & & 5,895 & \\ \text { No. of Observation } & 2,891 & & \end{array}$

Confidence Interval $* * * \alpha=1 \%, * * \alpha=5 \%, * \alpha=10 \%$

Source: constructed by author based on IFLS 2014

\section{Appendix 4.}

Descriptive Statistic of the Observable Variable Between the Treated and Control Group.

\begin{tabular}{lllllll}
\hline Variable & \multicolumn{3}{c}{ Treated Group (NFE=1) } & \multicolumn{3}{c}{ Control Group (NFE=0) } \\
\cline { 2 - 7 } & Obs. & Mean & Std. Dev & Obs. & Mean & Std. Dev \\
\hline sch_exp & 2,449 & $7,948,747$ & $1.11 \mathrm{e}+07$ & 3,496 & $5,684,809$ & $8,289,882$ \\
log_asset & 2,449 & 20.74298 & 1.853259 & 3,496 & 20.1769 & 2.265583 \\
female_hhh & 2,449 & .1535321 & .3605732 & 3,496 & .1973684 & .3980697 \\
dependrat & 2,449 & .5459791 & .4246758 & 3,489 & .5712402 & .4734451 \\
hhh_age & 2,449 & 49.37689 & 22.10406 & 3,496 & 49.4488 & 26.20556 \\
p_yos & 2,442 & 7.954136 & 4.376807 & 3,460 & 6.969364 & 4.449282 \\
\hline
\end{tabular}

Source: constructed by author based on IFLS 2014

\section{Appendix 5.}

Average Treatment on the Treated Result of School Expense between the Non-Farm Enterprise Household and the Household Without Non-Farm Enterprise.

\begin{tabular}{lccc}
\hline Matching Techniques & n. treated & n. control & $\begin{array}{c}\text { ATT } \\
\text { School Expenditure (Rp,00) }\end{array}$ \\
\hline Radius matching & 2,442 & 3,445 & $1,889,769.06^{* * *}$ \\
& & & $(266,723.828)$ \\
Nearest neighbor matching & 2,442 & 3,445 & $1,554,269.05 * * *$ \\
(NNM) & & & $(412,174.976)$ \\
Kernel matching & 2,442 & 3,445 & $1,286,790.04 * * *$ \\
& & & $(268,020.525)$ \\
\hline
\end{tabular}

Confidence Interval $* * * \alpha=1 \%,{ }^{* *} \alpha=5 \%,{ }^{*} \alpha=10 \%$, Standard errors are reported in parenthesis

Source: constructed by author based on IFLS 2014 